\title{
Lighting of indoor work places: risk assessment procedure
}

\author{
F. Leccese, G. Salvadori, M. Casini \& M. Bertozzi \\ Department of Energy and System Engineering, \\ Lighting and Acoustic Laboratory, University of Pisa, Italy
}

\begin{abstract}
In this paper the authors propose a procedure, based on in situ measurements, for risk assessment arising from lighting of indoor work places, paying particular attention to European technical legislation on lighting and standards on health and safety of workers.

Keywords: artificial lighting, indoor work places, risk assessment procedure, display screen equipment, in situ measurements.
\end{abstract}

\section{Introduction}

In the last few decades the work place has significantly changed, especially due to the widespread and prolonged use by workers of workstations with Display Screen Equipment (DES) [1]. The risk arising from artificial light sources during the course of work activities with DSE should be assessed by reference to ergonomics and vision aspects and it imply knowledge of word processing equipment that is used and of workstation layout [2-5]. In evaluating the lighting of work environment is necessary to consider the implications of ergonomics of vision arising from the relationship between the worker and the DSE (humanmachine interface), and the implications of the specific visual task with respect to the general lighting (human-environment interface).

The risk assessment arising from lighting becomes necessary to prevent or reduce health problems related to visual aspects (e.g. occupational asthenopia) and postural aspects (e.g. musculo-skeletal). In the technical literature the clinical survey is still poor and fragmented, in addition, there are no established procedures, of general validity, to allow the risk assessment in cases of inadequate lighting of the work place [4-6]. Within this context the authors 
propose a procedure for risk assessment arising from lighting of indoor work places, paying particular attention to European technical legislation on lighting (e.g. UNI EN 12464-1, UNI EN 1838, UNI EN 15193) and standards on health and safety of workers. With this purpose, the authors have carried out a measurements activity, of the main lighting parameters, in different indoor environments for office work, characterised by the prevalent use of DSE [6-9].

\section{Legislation and technical standards}

In the past in Italy, the general aspects concerning the lighting of work environment have been analysed in the dedicated legislation, for example:

- Circular of the Ministry of Public Works n.3151 (May 1967) on the evaluation criteria of the correct parameters in order to represent the thermal, hygrometric, ventilation and lighting features of building constructions;

- Circular of the Ministry of Public Works n.13011 (November 1974) on the thermo-physical requirements for hospital buildings (thermal and hygrometric behaviour, ventilation and lighting);

- Decree of the Minister of Public Works and Minister of Education of December 1975 on technical standards for school buildings;

- Legislative Decree n.626 (September 1994) on improving safety and health of workers at work which implements different European Directives, including in particular the Directive $90 / 270$ on the minimum safety and health requirements for work with DSE [1].

Recently, aspects of the risk assessment procedure arising from lighting (dayand artificial) in the work environment and arising from lighting of the work place with DSE have been included in [2].

It should be noted that aspects of the lighting work are usually treated together with other aspects of the indoor comfort conditions: temperature, humidity, ventilation [3]. As for lighting, the above cited legislation requires that: "The work place must have sufficient daylight and be equipped with devices that allow artificial lighting adequate to ensure the safety, health and welfare of workers", and it states also that: "the lighting devices of working areas and passageways must be installed so that the type of lighting does not pose a risk of accident to workers". Not surprisingly, as from these so generic indications (as specified in the legislation), it results in a very poor lighting in many work environments and sometimes inadequate, mainly in those environments where visual tasks are demanding [6-9].

A special case is represented by the lighting of work places with DSE [1-5]. The subject has been addressed in the legislation firstly in the Italian Legislative Decree 626/1994 (see previous list) and successively in the Decree of the Minister of Labour and Minister of Health in February 2000 on guidelines for the use of DSE. In the guidelines, technical requirements and design criteria for the work to the DSE were indicated in order to prevent the occurrence of musculoskeletal disorders, visual and mental fatigues. With reference to the DSE, the studies and the epidemiological investigations carried out so far allow to exclude specific risks from ionising and non-ionising radiation [10], moreover, the 
presence of the $\mathrm{CE}$ mark implies that electromagnetic fields are maintained below the recommended limits (valid for common living environments where electrical equipments like television are used).

Over the last ten years technical standards, concerning the lighting of the work place and the work with DSE, have undergone continuous upgrades in particular to take into account the evolutions of the work place and of the data processing systems. In Tables 1-2, the main European technical standards, currently adopted in Italy, concerning the lighting of the work place (see Table 1) and the lighting of workstations with DSE (see Table 2), are shown.

Table 1: Technical standards, state of the art in Italy (light and lighting applications).

\begin{tabular}{|l|c|c|}
\hline Title & Number & Year \\
\hline Lighting for work places - Part 1: Indoor work places & UNI EN 12464-1 & July 2011 \\
\hline $\begin{array}{l}\text { Interior lighting - Evaluation of the discomfort glare } \\
\text { using the glare rating method (UGR) }\end{array}$ & UNI 11165 & September 2005 \\
\hline Lighting applications - Emergency lighting & UNI EN 1838 & March 2000 \\
\hline $\begin{array}{l}\text { Energy performance of buildings - Energy requirements } \\
\text { for lighting }\end{array}$ & UNI EN 15193 & March 2008 \\
\hline
\end{tabular}

Table 2: $\quad$ Technical standards, state of the art in Italy (ergonomics).

\begin{tabular}{|l|c|c|}
\hline Title & Number & Year \\
\hline $\begin{array}{l}\text { Ergonomic requirements for office work with visual } \\
\text { display terminals (VDTs) - Part 5: Workstation layout } \\
\text { and postural requirements }\end{array}$ & $\begin{array}{c}\text { UNI EN ISO } \\
9241-5\end{array}$ & September 2001 \\
\hline $\begin{array}{l}\text { (..)- Part 6: Guidance on the work environment } \\
\text { UNI EN ISO } \\
9241-6\end{array}$ & October 2001 \\
\hline $\begin{array}{l}\text { (..)- Part 7: requirements for display with reflections } \\
\text { Ergonomics of human-system interaction - Part 300: } \\
\text { Introduction to electronic visual display requirements }\end{array}$ & $\begin{array}{c}\text { UNI EN ISO } \\
9241-300\end{array}$ & May 2002 \\
\hline $\begin{array}{l}\text { (...) - Part 302: Terminology for electronic visual } 2009 \\
\text { displays }\end{array}$ & $\begin{array}{c}\text { UNI EN ISO } \\
9241-302\end{array}$ & June 2009 \\
\hline $\begin{array}{l}\text { (...) - Part 303: Requirements for electronic visual } \\
\text { displays }\end{array}$ & $\begin{array}{c}\text { UNI EN ISO } \\
9241-303\end{array}$ & January 2012 \\
\hline $\begin{array}{l}\text { (...)- Part 306: Field assessment methods for electronic } \\
\text { visual displays }\end{array}$ & $\begin{array}{c}\text { UNI EN ISO } \\
9241-306\end{array}$ & May 2009 \\
\hline $\begin{array}{l}\text { (...)- Part 307: Analysis and compliance test methods } \\
\text { for electronic visual displays }\end{array}$ & $\begin{array}{c}\text { UNI EN ISO } \\
9241-307\end{array}$ & June 2009 \\
\hline
\end{tabular}

\section{Lighting design criteria}

Proper lighting of the work place is an essential aspect to ensure that workers can play in an efficient, accurate and safe their visual tasks, ensuring adequate levels of visibility and comfort [6]. Lighting should be comfortable and should communicate a sense of security, avoiding fatigue, discomfort and disabilities for the worker during the course of their activities. The lighting requirements are determined by the satisfaction of three basic human needs (UNI EN 12464-1): 
visual comfort (in an indirect way this also contributes to a higher productivity level and a higher quality of work), visual performance (the workers are able to perform their visual tasks, even under difficult circumstances and during longer periods), safety.

The main parameters determining the luminous environment with reference to artificial light and daylight are (UNI EN 12464-1): illuminance, luminance distribution, directionality of light, variability of levels and colour of light, colour rendering and colour appearance of the light, glare and flicker. There are other visual ergonomic parameters which influence visual performance (e.g. the intrinsic task properties such as size, shape, position, etc., the ophthalmic capacity of the person and the intentionally improved and designed luminous environment for persons with disabilities); these factors can enhance visual performance without the need for higher illuminance.

The illuminance and its distribution on the task area (see Table 3) and on the surrounding area have a great impact on how quickly, safely and comfortably a person perceives and carries out the visual task. The glare (discomfort or disability glare) is the sensation produced by bright areas within the visual field (e.g. lit surfaces; luminaires; windows). Glare shall be limited to avoid errors, fatigue and accidents. In indoor work places disability glare is not usually a major problem if discomfort glare limits are met. For the rating of discomfort glare from windows there is currently no standardized method. The rating of discomfort glare caused directly from the luminaires of an indoor lighting installation shall be determined using the UGR, CIE Unified Glare Rating (see Table 3). Flicker causes distraction and can give rise to physiological effects such as headaches. Stroboscopic effects can lead to dangerous situations by changing the perceived motion of rotating or reciprocating machinery. Lighting systems should be designed to avoid flicker and stroboscopic effects.

In Table 3 the maintained illuminance $\left(E_{m}\right)$ on the reference surface, the maximum value of $U G R\left(U_{G R}\right)$, the minimum illuminance uniformity $\left(\mathrm{U}_{0}\right)$ on the reference surface and the minimum value of colour rendering index (Ra) are specified in function of the type of area, task or activity (UNI EN 12464-1).

The distribution of the luminance values of the various surfaces including in the field of view influences, in a considerable manner, the adaptation of the eye of the observer at the lighting conditions, and then consequently it influences the performance of the visual tasks. In the technical standards, some reference ranges for the ratio between the luminance of the visual task and that of the surrounding surfaces are specified (see Table 4 [6]).

\section{Risk assessment procedure from lighting}

The risk arising from lighting is among the possible risks to which a worker can be exposed in their work environment, this risk is treated in Italy within the "requirements of the work place" [2]. Obviously postural aspects, in particular postural and visual ergonomics for DSE workstations, should be considered closely related to the lighting and in many cases evaluated jointly. A risk assessment procedure arising from lighting has been developed by the authors as 
Table 3: $\quad$ Indoor work places, minimum lighting requirements.

\begin{tabular}{|c|c|c|c|c|c|}
\hline \multicolumn{2}{|r|}{ Type of area, task or activity } & $\begin{array}{c}\mathbf{E}_{\mathbf{m}} \\
(\mathrm{lx})\end{array}$ & $\mathbf{U G R}_{\mathbf{L}}$ & $\mathbf{U}_{\mathbf{0}}$ & $\mathbf{R a}$ \\
\hline \multirow{4}{*}{ 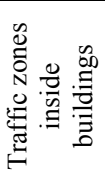 } & Circulation areas and corridors (1) & \multirow{3}{*}{100} & 28 & \multirow{6}{*}{0,40} & \multirow{4}{*}{40} \\
\hline & Stairs, escalators, travolators (2) & & \multirow{3}{*}{25} & & \\
\hline & Elevators, lifts (3) & & & & \\
\hline & Loading ramps/bays & 150 & & & \\
\hline \multirow{6}{*}{ 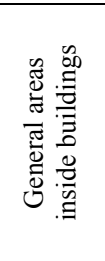 } & Rest rooms & 100 & 22 & & \multirow{2}{*}{80} \\
\hline & Cloakrooms, washrooms, bathrooms, toilets & 200 & 25 & & \\
\hline & Rooms for medical attention (4) & 500 & 16 & 0,60 & 90 \\
\hline & Plant rooms, switch gear rooms & 200 & 25 & 0,40 & 60 \\
\hline & Telex, post room, switchboard & 500 & 19 & 0,60 & 80 \\
\hline & Store and stockrooms (5) & 100 & 25 & 0,40 & 60 \\
\hline \multirow{7}{*}{$\begin{array}{l}\stackrel{\tilde{J}}{0} \\
\stackrel{\mathscr{E}}{0}\end{array}$} & Filing, copying, etc. & 300 & \multirow{2}{*}{19} & 0,40 & \multirow{14}{*}{80} \\
\hline & Writing, typing, reading, data processing (6) & 500 & & 0,60 & \\
\hline & Technical drawing & 750 & 16 & 0,70 & \\
\hline & CAD work stations (6) & 500 & 10 & & \\
\hline & Conference and meeting rooms (7) & 500 & 19 & 0,60 & \\
\hline & Reception desk & 300 & 22 & & \\
\hline & Archives & 200 & 25 & & \\
\hline \multirow{7}{*}{ 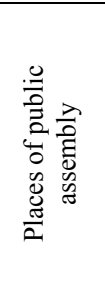 } & Entrance halls & 100 & 22 & 040 & \\
\hline & Corridors (8) & 100 & \multirow{3}{*}{25} & 0,40 & \\
\hline & Self-service restaurant & 200 & & & \\
\hline & Buffet & \multirow{2}{*}{300} & & 0,60 & \\
\hline & General lighting in exhibition halls & & 22 & 040 & \\
\hline & Bookshelves & 200 & 19 & 0,40 & \\
\hline & Reading area & 500 & 19 & 0,60 & \\
\hline
\end{tabular}

Note 1 - Illuminance at floor level; Ra and $\mathrm{UGR}_{\mathrm{L}}$ similar to adjacent areas; the lighting of exits and entrance shall provide a transition zone to avoid sudden changes in illuminance between inside and outside by day or night.

Note 2 - Requires enhanced contrast on the steps.

Note 3 - Light level in front of the lift should be at least $E_{\mathrm{m}}=200 \mathrm{~lx}$.

Note 4 - Colour temperature: $4000 \mathrm{~K} \leq \mathrm{T}_{\mathrm{C}} \leq 5000 \mathrm{~K}$.

Note $5-2001 x$ if continuously occupied.

Note 6 - See lighting of work stations with DSE (UNI EN 12464-1).

Note 7 - Lighting should be controllable.

Note 8 - During night-time lower levels are acceptable.

Table 4: $\quad$ Reference ranges for the values of the luminance ratio.

\begin{tabular}{|l|c|c|}
\hline \multirow{2}{*}{ Luminance ratio } & \multicolumn{2}{|c|}{ Type of environment (1) } \\
\cline { 2 - 3 } & $\mathbf{X}$ & \multicolumn{1}{|c|}{$\mathbf{Y}$} \\
\hline Between visual task $\left(\mathrm{L}_{\mathrm{V}}\right)$ and adjacent surfaces $\left(\mathrm{L}_{\mathrm{A}}\right)$ & \multicolumn{2}{|c|}{$1 / 3 \leq \mathrm{L}_{\mathrm{V}} / \mathrm{L}_{\mathrm{A}} \leq 3$} \\
\hline Between visual task $\left(\mathrm{L}_{\mathrm{V}}\right)$ and surrounding surfaces $\left(\mathrm{L}_{\mathrm{S}}\right)$ & $1 / 10 \leq \mathrm{L}_{\mathrm{V}} / \mathrm{L}_{\mathrm{S}} \leq 10$ & $1 / 20 \leq \mathrm{L}_{\mathrm{V}} / \mathrm{L}_{\mathrm{S}} \leq 20$ \\
\hline Between luminaires $\left(\mathrm{L}_{\mathrm{L}}\right)$ and surrounding surfaces $\left(\mathrm{L}_{\mathrm{S}}\right)$ & $\mathrm{L}_{\mathrm{L}} / \mathrm{L}_{\mathrm{S}} \leq 20$ & \\
\hline Between any sources $\left(\mathrm{L}_{1}\right.$ and $\left.\mathrm{L}_{2}\right)$ in the visual field & $\mathrm{L}_{1} / \mathrm{L}_{2} \leq 40$ & \\
\hline
\end{tabular}

Note 1- The environment is type $\mathrm{X}$ if the luminous reflections can be controlled, it is type $\mathrm{Y}$ if the reflections can be controlled only for the surfaces near the working area (very poor control for the other surfaces). 
part of a research activity carried out at the regional level on the hospitals of Tuscany Region [6]. As lighting risk factors can be identified: factors related to the visual task (e.g. the average illuminance and uniformity on the reference surface, the luminance ratio between visual task and surrounding surfaces), factors relating to the lighting systems (e.g. photometric data of luminaires and lamps), factors related to the emergency lighting. In the evaluation of these risk factors it is useful to consider, where appropriate, the contribution of daylight and of aspects related to the maintenance (e.g. work places and luminaires cleaning, lamp replacement). With the UNI EN 15193 some lighting design criteria, according to the UNI EN 12464-1 and grouped into three quality classes, have been introduced. These quality classes and their design criteria can be used for a definition of risk assessment procedure from lighting with a wide range of applicability to the work places (see Table 5).

Table 5: $\quad$ Lighting design criteria class.

\begin{tabular}{|c|c|c|c|}
\hline \multirow{2}{*}{ Requirements } & \multicolumn{3}{|c|}{ Lighting design class (1) } \\
\hline & $(*)$ & $(* *)$ & $(* * *)$ \\
\hline Maintained illuminance on horizontal visual task $\left(\mathrm{E}_{\mathrm{m}}\right)$ & $\mathbf{a ( 2 )}$ & - & ! \\
\hline Appropriate control of discomfort glare (UGR) & - & - & - \\
\hline Avoidance of flicker and stroboscopic effects & $\circ(2)$ & O & o \\
\hline Appropriate control of veiling reflections and reflected glare & & o & o \\
\hline Improved colour rendering $(\mathrm{Ra})$ & & 口 & - \\
\hline $\begin{array}{l}\text { Avoidance of harsh shadows or too diffuse light in order to } \\
\text { provide good modelling }\end{array}$ & & O & O \\
\hline Proper luminance distribution in the room & & O & O \\
\hline Special attention of visual communication in lighting faces & & & O \\
\hline Special attention to health issues & & & O \\
\hline
\end{tabular}

Note 1- With $(*)$ the basic fulfilment of requirements has been indicated; with $(* *)$ good fulfilment of requirements and with $(* * *)$ comprehensive fulfilment of requirements (UNI EN 15193).

Note 2 - With the black square the requirements from Tab. 3 have been indicated, with the white circle the "verbally described" requirements from UNI EN 12464-1 (UNI EN 15193).

\section{Study cases analysis}

As study cases, two offices of the Data Processing Centre of the "Campo Marte" Hospital in Lucca (Tuscany Region, Italy) have been selected (see Figures 1-2 [6]). The first office (hereinafter indicated with O1) has four workstations, the second office (indicated with $\mathrm{O} 2$ ) has one workstation, in all cases the working surfaces are desks with DSE. The offices are parallelepiped (with surface area equal to $40 \mathrm{~m}^{2}$ and $23 \mathrm{~m}^{2}$, respectively for $\mathrm{O} 1$ and $\mathrm{O} 2$, and net height equal to $2.7 \mathrm{~m}$ for both). The offices are equipped with windows (glass area of $6.4 \mathrm{~m}^{2}$ and $4.8 \mathrm{~m}^{2}$, respectively for $\mathrm{O} 1$ and $\mathrm{O} 2$ ), oriented towards the South-West equipped by manually adjustable shielding systems (internal venetian blinds with reclining slats and external rolling shutters). The internal surfaces of the two offices have the same colours and finishes: vertical walls plastered and coloured in light green (reflection coefficient $\mathrm{r}=0.6$ ), ceiling covered by light grey plasterboards panels $(\mathrm{r}=0.8)$ and floor covered by red porcelain $(\mathrm{r}=0.2)$ (see Figure 2$)$. 

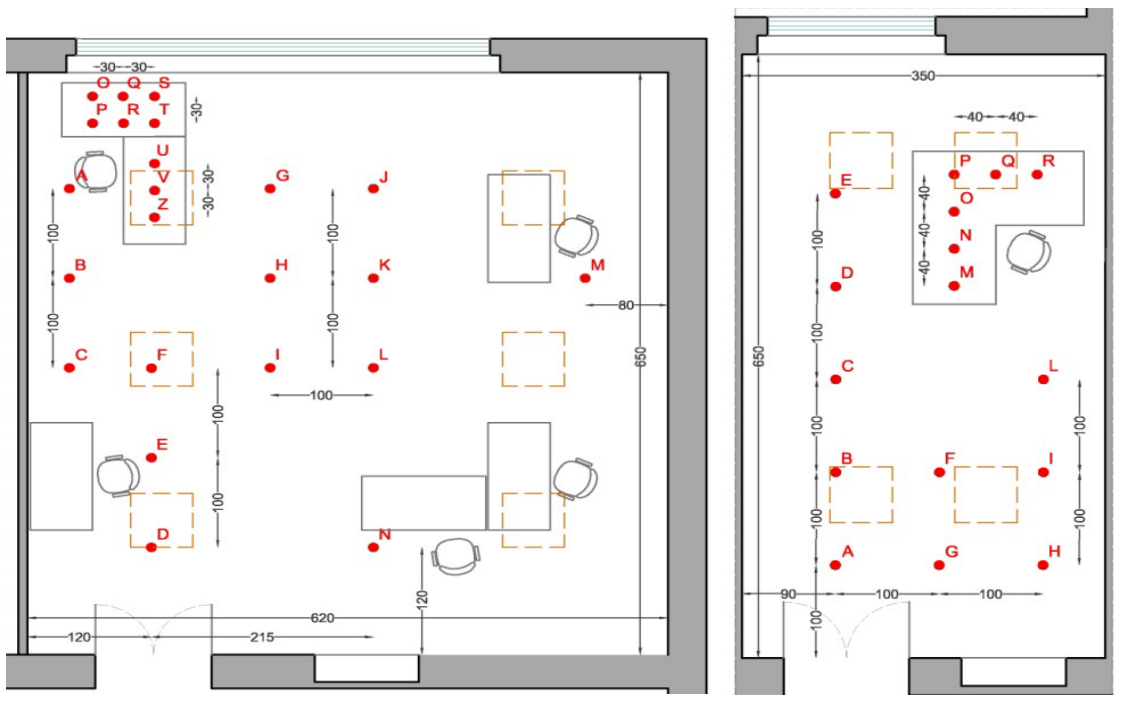

Figure 1: Plans: office O1 (left) and office O2 (right). Main dimensions, positions of the luminaires (dashed lines), main furniture and measurement points are indicated.
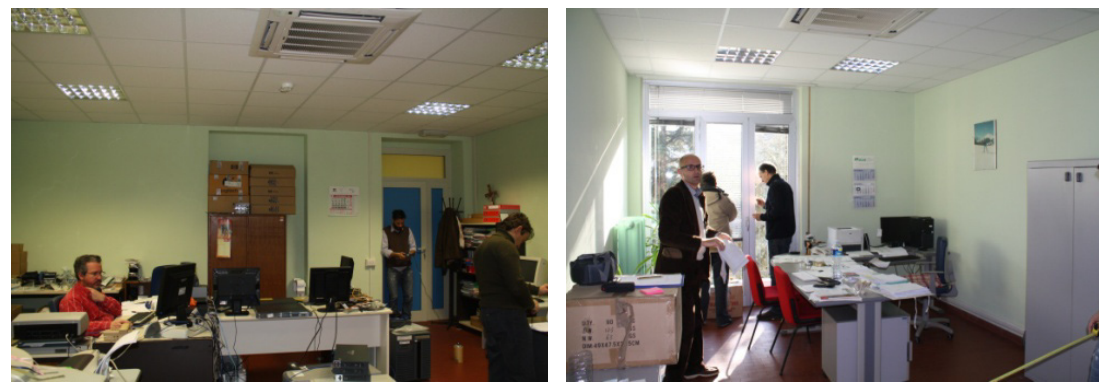

Figure 2: $\quad$ Pictures: office O1 (left) and office O2 (right).

In both offices are installed recessed luminaires with laminated aluminium reflective baffles equipped by 3 fluorescent lamps with nominal power of $18 \mathrm{~W}$ (see Figure 3). The luminaires are characterised by "dark-light" type photometric curves and optical efficiency of $66 \%$. The lamps have the following characteristics: luminous flux (at $25^{\circ} \mathrm{C}$ ) $1350 \mathrm{~lm}$, colour temperature $\mathrm{T}_{\mathrm{C}}=4000 \mathrm{~K}$ (cool white), colour rendering index $\mathrm{Ra}>80$, luminous efficiency $75 \mathrm{~lm} \cdot \mathrm{W}^{-1}$, operating lifetime of to $18000 \mathrm{~h}$.

The visual tasks most frequently performed in the two offices are: data processing to the DSE (vision of the keyboard for data input and vision of the DSE for data reading), processing documents at desk (reading and writing on paper). For these visual tasks it is necessary fulfil the minimum requirements shown in Table 3 (Offices) and the specified luminance ratios in Table 4, 

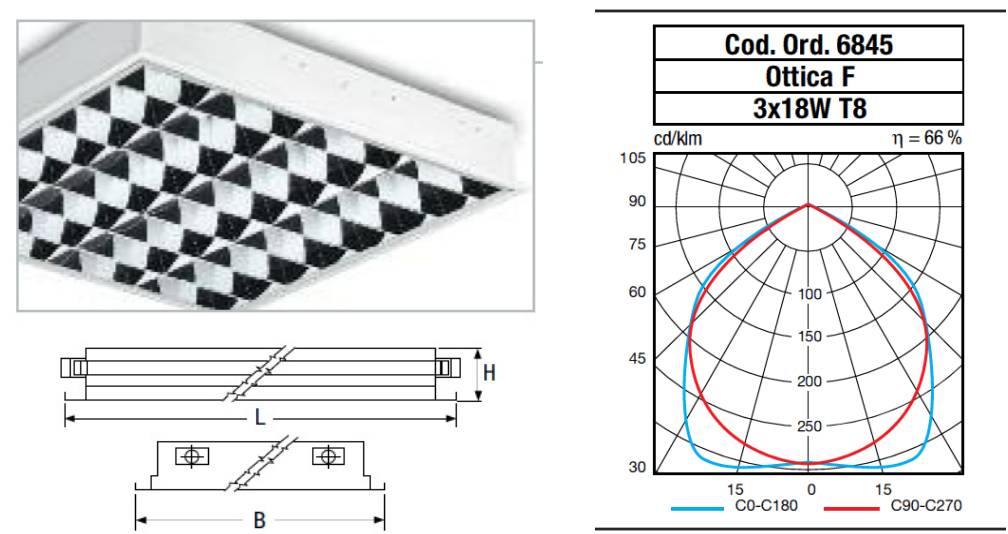

Figure 3: Features of the installed luminaires: picture and sketch (left, where $\mathrm{L}=\mathrm{B}=620 \mathrm{~mm}, \mathrm{H}=90 \mathrm{~mm}$ ); photometric curves (right).

considering the DSE and the paper on the desk as visual tasks and the walls of the environment as background surfaces.

The fulfilment of the minimum requirements specified in the technical standards has been verified by in situ measurements of illuminance and luminance, with appropriate measurement instruments (e.g. illuminance meter and luminance meter). The measurements have been carried out considering four different lighting scenarios (more frequently adopted): only daylight (scenario $\mathrm{S} 1$ ), partial shielded daylight (S2, characterised by a horizontal position of the reclining slats), partial shielded daylight integrated by artificial light (S3), only artificial light (S4). The measurement points have been placed on a surface at height $h_{\mathrm{F}}=0.2 \mathrm{~m}$ from the floor (floor level) and on the desks at height $\mathrm{h}_{\mathrm{W}}=0.85 \mathrm{~m}$ from the floor (workplanes). In order to verify the lighting fulfilments, 14 points on the ground level and 9 points on the workplane which is located near the window (the most critical position for the risk arising from lighting) have been used in the office $\mathrm{O} 1$ (see Figure 1, left). While 10 points on the ground level and 6 points on the workplane have been used in the office $\mathrm{O} 2$ (see Figure 1, right).

The measurement results are summarized in Table 6. It is worth noting that the illuminance measurements (in the case of daylight) have been conducted in partially overcast sky condition. From interviews to workers it has been pointed out that, in the case of clear sky, the shielding system is always used with the slats reclined between $30^{\circ}$ and $45^{\circ}$ (with respect to the vertical plane) to avoid direct penetration of solar radiation, considered by each of the workers as a source of discomfort (visual discomfort). For both offices and for the analysed surfaces (floor levels and workplanes) the minimum and maximum values of illuminance are shown (in bold) in Table 6. From the measurements it can be pointed out as the daylight (S1) produces a marked non-uniformity of illuminance on the analysed surfaces. The use of the shielding systems (S2) and the integration with artificial light (S3) can significantly reduce this non- 
Table 6: $\quad$ Measurements results of illuminance for both offices.

\begin{tabular}{|c|c|c|c|c|c|}
\hline & & Of & e 0 & & \\
\hline & & S1 & S2 & S3 & S4 \\
\hline & & & lumir & cee $(1 \mathrm{x})$ & \\
\hline & A & 170 & 310 & 620 & 305 \\
\hline & B & 154 & 410 & 830 & 398 \\
\hline & $\mathrm{C}$ & 130 & 330 & 780 & 375 \\
\hline & $\mathrm{D}$ & 96 & 210 & 450 & 266 \\
\hline & $E$ & 92 & 170 & 524 & 397 \\
\hline$=$ & $\mathrm{F}$ & 63 & 154 & 570 & 484 \\
\hline 己 & $\mathrm{G}$ & 582 & 360 & 650 & 334 \\
\hline & $\mathrm{H}$ & 384 & 566 & 870 & 430 \\
\hline $\overrightarrow{I I}$ & I & 250 & 510 & 878 & 452 \\
\hline & $\mathrm{J}$ & 560 & 380 & 620 & 297 \\
\hline & $\mathrm{K}$ & 440 & 400 & 730 & 408 \\
\hline & $\mathrm{L}$ & 330 & 330 & 610 & 283 \\
\hline & $\mathrm{M}$ & 80 & 100 & 565 & 470 \\
\hline & $\mathrm{N}$ & 43 & 55 & 293 & 240 \\
\hline & $\mathrm{O}$ & 3600 & 660 & 812 & 261 \\
\hline & $\mathrm{P}$ & 3300 & 829 & 1038 & 292 \\
\hline & $\mathrm{Q}$ & 3500 & 730 & 967 & 296 \\
\hline 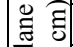 & $\mathrm{R}$ & 3100 & 800 & 1140 & 331 \\
\hline 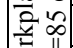 & $\mathrm{S}$ & 3300 & 730 & 1148 & 322 \\
\hline$\sum^{0}$ & $\mathrm{~T}$ & 3100 & 820 & 1250 & 367 \\
\hline & $\mathrm{U}$ & 2900 & 830 & 1430 & 415 \\
\hline & $\mathrm{V}$ & 2400 & 800 & 1428 & 491 \\
\hline & $Z$ & 1400 & 550 & 1235 & 578 \\
\hline
\end{tabular}

\begin{tabular}{|c|c|c|c|c|c|}
\hline \multicolumn{6}{|c|}{ Office $\mathrm{O} 2$} \\
\hline \multirow{2}{*}{\multicolumn{2}{|c|}{$\begin{array}{c}\text { Scenario } \\
\begin{array}{c}\text { Measur. } \\
\text { point }\end{array}\end{array}$}} & S1 & S2 & S3 & S4 \\
\hline & & \multicolumn{4}{|c|}{ Illuminance (lx) } \\
\hline \multirow{10}{*}{ 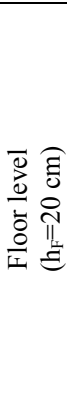 } & $\mathrm{A}$ & 157 & 150 & 508 & 467 \\
\hline & $\mathrm{B}$ & 232 & 270 & 582 & 530 \\
\hline & $\mathrm{C}$ & 370 & 250 & 640 & 540 \\
\hline & $\mathrm{D}$ & 830 & 460 & 605 & 350 \\
\hline & $\mathrm{E}$ & 1470 & 560 & 930 & 450 \\
\hline & $\mathrm{F}$ & 45 & 62 & 684 & 550 \\
\hline & $\mathrm{G}$ & 105 & 97 & 620 & 618 \\
\hline & $\mathrm{H}$ & 75 & 66 & 510 & 452 \\
\hline & I & 78 & 82 & 590 & 540 \\
\hline & $\mathrm{L}$ & 100 & 86 & 590 & 525 \\
\hline \multirow{6}{*}{ 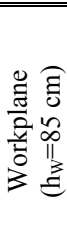 } & M & 150 & 150 & 785 & 650 \\
\hline & $\mathrm{N}$ & 210 & 170 & 900 & 706 \\
\hline & $\mathrm{O}$ & 260 & 210 & 1050 & 750 \\
\hline & $\mathrm{P}$ & 325 & 230 & 1030 & 757 \\
\hline & $Q$ & 110 & 65 & 830 & 700 \\
\hline & $\mathrm{R}$ & 86 & 55 & 515 & 430 \\
\hline
\end{tabular}

uniformity. In the case of only artificial light (S4) the uniformity is obviously the higher measured.

In the scenario S4 (only artificial light), from the measurements results, the average illuminance and the uniformity values can be calculated (see Table 7) and directly compared with the standard values reported in Table 3 . Note that the average illuminance $\left(\mathrm{E}_{\mathrm{m}}\right)$ of a specific workplane can be calculated as the arithmetic mean of all measurements made on the plane or alternatively as the arithmetic mean of the maximum and minimum values measured on the same plane. In Table 7 are shown the results of both calculations (in brackets the value obtained as the arithmetic mean of maximum and minimum values). For example in the office $\mathrm{O} 1$ the difference between the results of two calculations is less than $2 \%$ for the ground level and it is less than $12 \%$ for the workplane, similar results are obtained for the office $\mathrm{O} 2$. From Table 7 it can be seen as the average illuminance calculated on the workplane in $\mathrm{O} 1$ is lower than the standard value of $500 \mathrm{~lx}$ (see Table 3 ) of about $25 \%$, on the contrary on the workplane in 
Table 7: $\quad$ Scenario (S4), analysis of measured values of illuminance.

\begin{tabular}{|l|l|c|c|}
\hline Surface & Lighting parameter & Office O1 & Office O2 \\
\hline \multirow{4}{*}{$\begin{array}{l}\text { Floor level } \\
\left(\mathrm{h}_{\mathrm{F}}=20 \mathrm{~cm}\right)\end{array}$} & Minimum illuminance $\left(\mathrm{E}_{\min }, \mathrm{lx}\right)$ & 240 & 350 \\
\cline { 2 - 4 } & Maximum illuminance $\left(\mathrm{E}_{\max }, \mathrm{lx}\right)$ & 484 & 618 \\
\cline { 2 - 4 } & Average illuminance $\left(\mathrm{E}_{\mathrm{m}}, \mathrm{lx}\right)$ & $367(362)$ & $502(484)$ \\
\cline { 2 - 4 } & Uniformity of illuminance $\left(\mathrm{U}_{0}\right)$ & $0.65(0.66)$ & $0.70(0.72)$ \\
\hline \multirow{3}{*}{$\begin{array}{l}\text { Workplane } \\
\left(\mathrm{h}_{\mathrm{W}}=85 \mathrm{~cm}\right)\end{array}$} & Minimum illuminance $\left(\mathrm{E}_{\min }, \mathrm{lx}\right)$ & 261 & 430 \\
\cline { 2 - 4 } & Maximum illuminance $\left(\mathrm{E}_{\max }, \mathrm{lx}\right)$ & 578 & 757 \\
\cline { 2 - 4 } & Average illuminance $\left(\mathrm{E}_{\mathrm{m}}, \mathrm{lx}\right)$ & $373(420)$ & $665(593)$ \\
\cline { 2 - 4 } & Uniformity of illuminance $\left(\mathrm{U}_{0}\right)$ & $0.70(0.62)$ & $0.65(0.73)$ \\
\hline
\end{tabular}

$\mathrm{O} 2$ it is higher of $30 \%$. Because the differences between the calculated and the standard values, in particular for the office $\mathrm{O} 1$ an increase of the illuminance level on the workplane should be considered (e.g. by changing the lamps or increasing the number of luminaires). The uniformity of illuminance, on the workplanes of both offices, fulfils the standard value $\left(\mathrm{U}_{0}>0.6\right.$, see Table 3$)$.

In order to evaluate the adequacy of the luminance ratios between the surfaces of the visual tasks (e.g. DSE, keyboard, white paper) and other surfaces in the field of view (e.g. background walls, windows, doors), for the main directions of view shown in Figure 4, in situ measurements of luminance have been carried out.
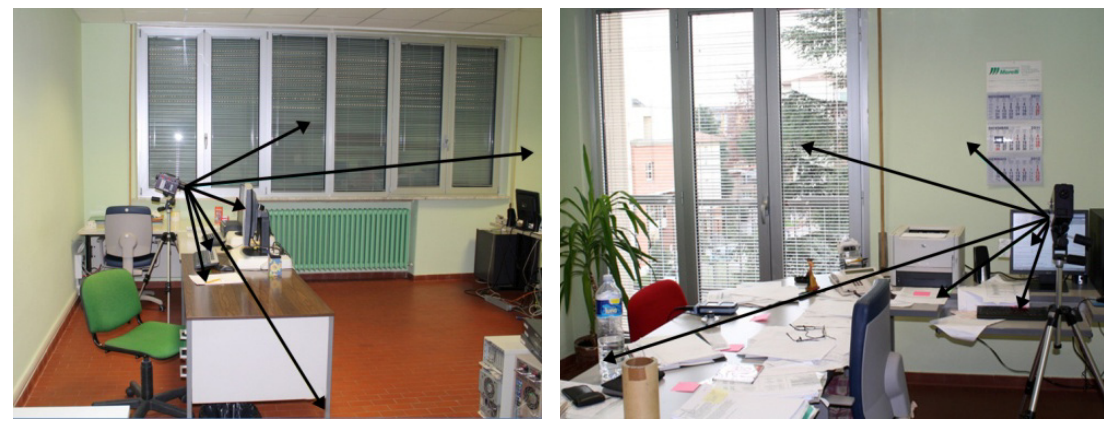

Figure 4: $\quad$ Main directions of view, office $\mathrm{O} 1$ (left), office O2 (right).

The measurements results are summarised in Table 8. From Table 8, by considering for example the office $\mathrm{O} 1$, it can be observed that the ratios between the measured values of luminance $\left(\mathrm{L}_{\mathrm{V}}\right)$ of the more relevant visual task (direction of view $A$ ) and the measured values of luminance $\left(\mathrm{L}_{\mathrm{S}}\right)$ of the surrounding surface in the visual field (direction of view D) are included in the range $1 / 10 \div 10$ for all the analysed scenarios, according to the values indicated in Table 4. Similar results are obtained for the office $\mathrm{O} 2$ for the same directions of view (A and D).

Moreover by considering the keyboard as surrounding surface (direction of view $B$, which is included in the visual field during the DSE reading) the 
Table 8: $\quad$ Scenario (S4), analysis of measured values of luminance.

\begin{tabular}{|c|c|c|c|c|c|c|}
\hline & Direction of view & $\begin{array}{l}\text { Inclination angle } \\
\text { with respect to the } \\
\text { horizontal plane }\end{array}$ & \multicolumn{4}{|c|}{ Lighting scenario } \\
\hline \multicolumn{7}{|c|}{ Office 01} \\
\hline & & & S1 & $\mathbf{S 2}$ & S3 & S4 \\
\hline $\mathbf{A}$ & Toward the DSE & $20^{\circ}$ & 77 & 67 & 48 & 71 \\
\hline B & Toward the keyboard & $40^{\circ}$ & 28 & 20 & 7 & 13 \\
\hline $\mathbf{C}$ & Toward the white paper & $60^{\circ}$ & 660 & 266 & 192 & 97 \\
\hline D & Toward background & horizontal & 140 & 86 & 95 & 45 \\
\hline $\mathbf{E}$ & Toward the window & horizontal & 725 & 704 & 972 & 11 \\
\hline $\mathbf{F}$ & Toward the entrance door & horizontal & 58 & 51 & 63 & 6 \\
\hline \multicolumn{7}{|c|}{ Office $\mathrm{O2}$} \\
\hline & & & S1 & $\mathbf{S 2}$ & S3 & S4 \\
\hline $\mathbf{A}$ & Toward the DSE & $20^{\circ}$ & 139 & 137 & 148 & 138 \\
\hline B & Toward the keyboard & $40^{\circ}$ & 3 & 2 & 8 & 10 \\
\hline $\mathbf{C}$ & Toward the white paper & $60^{\circ}$ & 37 & 20 & 113 & 150 \\
\hline D & Toward background & horizontal & 15 & 15 & 52 & 58 \\
\hline $\mathbf{E}$ & Toward the window & horizontal & 752 & 530 & 415 & 12 \\
\hline $\mathbf{F}$ & Toward the entrance door & horizontal & 11 & 11 & 28 & 22 \\
\hline
\end{tabular}

luminance ratios between these surfaces can be evaluated. In this case, for the office $\mathrm{O} 1$ (light grey keyboard), the ratios $\mathrm{L}_{\mathrm{V}} / \mathrm{L}_{\mathrm{S}}$ are included in the range $1 / 10 \div 10$ for all the analysed scenarios, according to the values indicated in Table 4 (the same results are obtained for both offices by considering as surrounding surface the white paper, direction of view $\mathrm{C}$ ). On the contrary for the office $\mathrm{O} 2$ (black keyboard), the ratios $\mathrm{L}_{\mathrm{V}} / \mathrm{L}_{\mathrm{S}}$ overcome the maximum value of 40 (see Table 4) in the case of daylight (scenarios S1 and S2) and they are in the range $1 / 20 \div 20$ in the case of artificial light (scenarios S3 and S4). In this latter case, the use of a clear keyboard (black keyboard instead) can bring the luminance ratios inside the reference range (see Table 4).

Finally by considering the ratios between the luminance $\left(\mathrm{L}_{1}\right)$ of the DSE (direction of view $\mathrm{A}$ ) and the luminance $\left(\mathrm{L}_{2}\right)$ of the window (direction of view E), it can be observed that the ratios L1/L2 are lower than the maximum value of 40 (see Table 4) for all the analysed scenarios.

\section{Conclusive remarks}

Aspects of the risk assessment procedure arising from lighting is generically treated in Italian legislation within the "requirements of the work place". As a consequence of the generic indications of the legislation, it can usually find poor or inadequate lighting in many work environments. The in situ measurements activity and the analysis of the results discussed by the authors, even if applied to specific cases, are characterised by general validity, easiness of application and they take into account all the lighting parameters able to influence the visual comfort, the health and the safety of the workers. The proposed procedure can be 
used in order to perform risk assessment arising from lighting for a lot of indoor work environments according to the international legislation on health and safety of workers.

\section{Acknowledgements}

This research activity has been partially carried out within the "Triennial program for staff training of the Prevention and Protection Services (PPS) of the 16 Tuscan Public Health Companies and the formulation of specific risk assessment criteria - Topic 3: Ergonomics (Lighting, Work places equipped by $D S E$ )" funded by Tuscany Region (2010-1012). PPS Workgroup: AUSL 1 Massa and Carrara (M. Venturotti, B. Riani, G. Carosi, A. Moriconi, M. Bacchi), AUSL 2 Lucca (S. Surlinelli, R. Giorgi, M. Buoni), AUSL 3 Pistoia (L. Lippi, A. Carrara, P. Giraldi, R. Forzoni, S. Biagini), AUSL 4 Prato (R. Mennini, D. Corbo, G. Ausilio), AUSL 5 Pisa (C. Montagnani, C. Gozzini, A. Boni, V. Pioni), AUSL 6 Livorno (A. Taddeo, S. Neri, P. Lambardi, G. Conti, A. Torri), AUSL 7 Siena (L. Lazzeri, S. Gepponi, C. Monaci, D. Cavarra, R. Fontani), AUSL 8 Arezzo (M. Cacioli, C. Cardeti, A.B. Costa, Y. Bacchi), AUSL 9 Grosseto (T. Vetrugno, D. Solari, G. Savelli, M. Ghini, D. Bulleri) AUSL 10 Firenze (B. Perazzi, P. Benucci, A. Collini, T. Fabriani, R. Francioli, I. Gaddini, F. Gheri, C. Manière, A. Mazzucchielli, L. Modesti, A. Olivieri, R. Ricciardi, G. Rossi, N. Vanni), AUSL 11 Empoli (G. Falcioni, O. Biocca, M. Fastelli, F. Arcieri, F. Marzano, G. Neri), AUSL 12 Viareggio (M. Cirilli, R. Bianchi, M. Iacomini, R. Ciliberti), AOU Careggi-Firenze (M. Raugei, N. Li Vigni, E. Bongini, S. Bianchini), AOU Meyer-Firenze (G. Verdolini, G. Soro), AOU Pisa (L. Zuccoli, G. Ceccanti, F. Escati, S. Manzi), AOU Siena (C. Rossi). Head of Triennal Aimed Program: AUSL 5 Pisa - Claudia Carloni (Head U.O. Training). Organization Secretariat (Coordination and Tutoring): G.E.C.O. Eventi Emanuela Ferro, Cristina Rosamilia.

\section{References}

[1] Council Directive 90/270/EEC of 29 May 1990 on the minimum safety and health requirements for work with display screen equipment (Official Journal of the European Communities L 156, pp. 14-18).

[2] Decreto Legislativo del 9 Aprile 2008, n. 81, Attuazione dell'Articolo 1 della Legge 3 agosto 2007 n. 123 in materia di tutela della salute e della sicurezza nei luoghi di lavoro (in Italian).

[3] Coordinamento Tecnico Interregionale della Prevenzione nei Luoghi di Lavoro \& Istituto Superiore per la Prevenzione e la Sicurezza sul Lavoro (ISPESL), Microclima, aerazione e illuminazione nei luoghi di lavoroRequisiti e standard - Indicazioni operative e progettuali - Linee Guida, June 2006 (in Italian).

[4] Istituto Nazionale per l'Assicurazione contro gli Infortuni sul Lavoro (INAIL), Il lavoro al videoterminale, ed. B. Manfredi, INAIL - Direzione Centrale Comunicazione, Roma, 2010 (in Italian). 
[5] Istituto Nazionale per l'Assicurazione contro gli Infortuni sul Lavoro (INAIL), Il Medico Competente e gli Addetti ai Videoterminali, eds. L. Bindi, M. Clemente, A. Miccio, A. Ossicini, INAIL - Sovrintendenza Medica Generale, Roma, 2010 (in Italian).

[6] F. Leccese, G. Salvadori, M. Casini, M. Bertozzi, Risk Assessment illuminotecnico in ambiente ospedaliero - Risultati di una ricerca condotta a livello regionale, GECO Eventi: Pisa, ISBN 978-88-907334-0-6, June 2012 (in Italian).

[7] Corucci T., Ergonomia della visione nelle postazioni di lavoro fisse munite di videoterminale - Normativa, caso di studio e misure in opera, Tesi di Laurea in Ingegneria Edile (relatori: F. Leccese, G. Salvadori, M. Bertozzi), Pisa, 2011 (in Italian).

[8] Bertozzi M., Casini M., Leccese F., Salvadori G., Illuminazione nei luoghi di lavoro: benessere, salute e sicurezza dei lavoratori. IF CRASC $2012-$ Proc. of the 2nd Convegno Nazionale di Ingegneria Forense, Pisa, November 2012, to be published (in Italian).

[9] Leccese F., Salvadori G., Casini M., Bertozzi M., Rischio illuminotecnico nelle postazioni fisse di lavoro con videoterminale. IF CRASC 2012 - Proc. of the 2nd Convegno Nazionale di Ingegneria Forense, Pisa, November 2012, to be published (in Italian).

[10] Leccese F., Salvadori G., Casini M., Bertozzi M., Artificial Optical Radiation (AOR) due to lighting sources in indoor work places. RISK ANALYSIS 2012 - Proc. of the $8^{\text {th }}$ International Conference on Risk Analysis and Hazard Mitigation, Island of Brač (Croatia), 19-21 September 2012. 